Malayalam name: Kattamrithu, Pothan amrithu.

\section{TINOSPORA SINENSIS (LOUR.) MERR. FROM SICKUPARA, KOLLI HILLS FOREST, NAMAKKAL DISTRICT, TAMIL NADU}

\section{P.S. Udayan, Satheesh George, K.V. Tushar, and Indira Balachandran}

Centre for Medicinal Plants Research (CMPR), Arya Vaidya Sala, Kottakkal, Malappuram District, Kerala 676503

Email: avscmpr@sify.com / avscmpr@yahoo.co.in

Web supplement

Kolli Hill or Kollimalai is located near Rasipuram Taluk of Namakkal District in Tamil Nadu $\left(11^{0} 10^{\prime}-11^{0} 30^{\prime} \mathrm{N} \& 7^{0} 15^{\prime}-78^{0} 30^{\prime} \mathrm{E}\right.$, $1000-1400 \mathrm{~m})$. A small area of the eastern portion of these hills lies in the Perambalur District. The total Kollimalai area of $283 \mathrm{~km}^{2}$ is part of the Talaghat stretch and to the east lie the Patchamalai. A broad valley divides Kollimalai and Patchamalai. Kollimalai appears to be abruptly ascending from the plains on the western, eastern and southern sides and descending to the plains by numerous long and gently sloping spurs on the northern side. The maximum temperature ranges between $20^{\circ} \mathrm{C}$ and $30^{\circ} \mathrm{C}$ and minimum temperature between $10^{\circ} \mathrm{C}$ and $20^{\circ} \mathrm{C}$. The average annual rainfall is around $1445 \mathrm{~mm}$. The soil type is deep to very deep and is non-calcareous. The topmost hill area is characterised by sandy-loam soil where as the bottom of the valley is characterised by alluvial and clayey-loam soil. The forest types range from evergreen to moist deciduous and dry deciduous. On the western side of the hills, good shola patches still exist, though a great portion of the plateau is cleared.

Earlier studies on flora of Tamil Nadu do not record the occurence of this species in the state (Nair \& Henry, 1983; Matthew, 1981, 1983, 1984, 1991, 1996, 1999; Pallithanam, 2001).

The present survey conducted in the Kolli Hills resulted in the collection of 70 taxa of angiosperms. Out of these, Tinospora sinensis (Lour.) Merr. has not been reported in any of the previous publications on the flora of Tamil Nadu. It is enumerated here with updated nomenclature, brief description, phenological data, distribution, specimens examined and notes for better understanding of this taxon. The voucher specimens are deposited at the Centre for Medicinal Plants Research (CMPR), Kottakkal.

\section{Tinospora sinensis (Lour.) Merr.}

Tinospora sinensis (Lour.) Merr. in Sunyatsenia 1: 193. 1934 \& Trans. Am. Phil. Soc. Philad. 24: 158. 1935; Forman, Kew Bull. 36: 1981; Ramesh in Sald., Fl. Karnataka 1: 101. 1984; Sasi. \& Sivar., Fl. Plants of Thrissur Forests 39. 1996; Sivar. \& Philip Mathew, Fl. Nilambur 51. 1997; A. Pramanik in Sharma et al., Fl. India 1: 349. 1993. Campylus sinensis Lour., Fl. Cochinch. 113. 1790. Menispermum malabaricum Lam., Encycl. Meth. 4: 96. 1797. Cocculus tomentosa Colebr. in Trans. Linn. Soc. Lond. 13: 56. 1872. T. malabarica (Lam.) Hook.f. \& Thoms., Fl. Ind. 1: 183. 1855 \& in Hook.f., Fl. Brit. India 1: 96. 1872. T. tomentosa (Colebr.) Hook.f. \& Thoms., Fl. Ind. 1: 183. 1855 \& in Hook.f., Fl. Brit. India 1: 96: 1872. (Menispermaceae)
Specimen examined: 19.ii.04, Sickupara, Kolli Hills, ca.1400m, coll. P.S. Udayan et al., CMPR 02368

Distribution: India, Sri Lanka, Nepal, Bangladesh, Myanmar, China, Thailand, Vietnam and Cambodia. In India it occurs in Assam, Bihar, Orissa, Maharashtra, Andhra Pradesh, Karnataka, Kerala and now reported for the first time from Tamil Nadu.

Description: Large fleshy deciduous climber; mature stem shiny, bark papery. Young parts tomentose; latex light, yellowish, watery. Leaves broadly ovate to suborbicular, 5-16 x 4-12cm, membranous, sparingly pubescent above, pilose beneath with glandular patches at basal nerve axils, acutely acuminate at apex, abruptly truncate or cuneate or subcordate at base; lateral nerves 5-7 pairs; petioles 5-12 cm long, puberulous, thickened at base. Flowers greenish-yellow, in racemes or panicles, axillary or from the old stem; panicles 3-12 cm long, slender. Male flowers: pedicels 2-5mm long; sepals yellowish-green, glabrous; outer three ovate, $1-1.5 \mathrm{~mm}$ long; inner three broadly elliptic, 3-5 x 2$5 \mathrm{~mm}$; petals six, obliquely rhomboid-ovate, $3-4$ x 1-3mm; stamens ca. 1.5-2mm long; anthers dehiscing longitudinally. Female flowers: carpels three, stigma flat, 2-lobed, staminodes six, clavate; gynophore ca. $1 \mathrm{~mm}$ long. Drupes globose, 1-3, 10-13mm across, red, scarlet or orange red; carpophores $2-3 \mathrm{~mm}$ long on 8$10 \mathrm{~mm}$ long peduncles; endocarp rugose, dorsally keeled and ventrally concave, $7-9 \times 5-6 \mathrm{~mm}$, tuberculate (Image $1^{\mathrm{w}}$ ).

Habitat: Climbing on Ficus arnottiana and Schefflera stellata along the rocky valleys of mixed deciduous forests.

Phenology: Flowering and Fruiting: February - June.

Remarks: In India, four species of Tinospora are found. Out of this only two species are present in southern India, viz., Tinospora cordifolia and T. sinensis. T. glabra occurs in Andaman Islands and T. crispa is found in northeastern region. This species can be easily recognised by the presence of puberulous hairs throughout the plant when young. The red listed status of this species is "Vulnerable" for Karnataka, "Lower Risk near Threatened" for Kerala and "Not evaluated" for Tamil Nadu. The Flora of India and all the published floras of Tamil Nadu do not make any mention of its occurrence in the state of Tamil Nadu. So, the present collection of this species is not only a new report to the Tamil Nadu but also an extension of distribution further towards the southern parts of the Eastern Ghats of Andhra Pradesh. Only two mature individuals were recorded from Kolli Hills. In Kerala it is fairly common in moist deciduous to semi-evergreen forests.

Medicinal uses: Stems are used for treating piles, ulcerated wounds, liver complaints, chronic rheumatism and also as muscle relaxant. It is also used as a substitute for Tinospora cordifolia (Amrita).

\section{REFERENCES}

Matthew, K.M. (1981-1984). The Flora of Tamilnadu Carnatic, Vols.IIII. The Rapinat Herbarium, St. Joseph's College, Thiruchirapalli.

w See Image 1 in the web supplement at www.zoosprint.org 
Matthew, K.M. (1991). An Excursion Flora of Central Tamil Nadu, India. The Rapinat Herbarium, St. Joseph College, Thiruchirapalli.

Matthew, K.M. (1996). Illustrations on the Flora of the Palni Hills, South India. The Rapinat Herbarium, St. Joseph College, Thiruchirapalli. Matthew, K.M. (1999). The Flora of the Palni Hills, South India, Part. I. The Rapinat Herbarium, St. Joseph College, Thiruchirapalli.

Nair, N.C., A.N. Henry, G.R. Kumari \& V. Chithra (1983). Flora of Tamil Nadu, India, Ser. 1: Analysis. Vol. 1. Botanical Survey of India, Calcutta.

Pallithanam, J.M. (2001). In: Matthew, K.M. (Ed.). A Pocket Flora of the Sirumalai Hills, South India. The Rapinat Herbarium, St. Joseph College, Thiruchirapalli.

\section{ACKNOWLedGements}

The authors are thankful to the authorities of Arya Vaidya Sala (AVS), Kottakkal and Department of Biotechnology, Government of India, for the financial support. We are also greatly indebted to Dr. P.N. Ravindran, Coordinating Director, CMPR, for his constant encouragement and support. We express our gratitude to the authorities of Tamil Nadu Forest Department and Mr. U. Ravindran, I.F.S., Divisional Forest Officer, Salem Forest Division, Salem and Mr. Eshwara Murthy, Range Officer, Kolli Hills Range, Namakkal district, for granting permission and arranging forest staffs for the field visit. We are also thankful to Mr. N.K. Janardhanan staff of AVS Herbal Garden, for assisting during the field visit.

\section{NEW RECORD}

ZOOS' PRINT JOURNAL 19(9): 1623-1624

\section{GYMNEMA KHANDALENSE SANTAPAU - A RARE AND LITTLE KNOWN ENDEMIC RED LISTED MEDICINAL PLANT FROM NILAKKAL FOREST, KERALA}

\section{P.S. Udayan, K.V. Tushar, Satheesh George and Indira Balachandran}

Centre for Medicinal Plants Research (CMPR), Arya Vaidya Sala, Kottakkal, Malappuram District, Kerala

web supplement

A botanical survey was conducted in Nilakkal forest near Sabarimala of Pathanamthitta District $\left(09^{\circ} 16^{\prime}-09^{0} 24^{\prime} \mathrm{N} \& 76^{0} 47^{\prime}\right.$ $\left.77^{\circ} 04^{\prime} \mathrm{E}\right)$, Kerala, to collect medicinal plants for the establishment of a germplasm bank at Kottakkal, Malappuram District. During the survey an interesting species of Gymnema was collected. Critical studies have confirmed it as Gymnema khandalense. The specimens have also been compared with the specimens housed in the herbarium of Kerala Forest Research Institute, (KFRI), Peechi. This species was so far known only from the type locality in the Khandala forests of Western Ghats in Maharashtra collected by Santapau in 1944-45. After a period of 34 years, Kothari and Moorthy could collect the plant in 1979 from Raigad District of Maharashtra State. Sasidharan (1996) reported this species from Vazhachal forests of Thrissur District, Kerala, extending its distribution further towards southern Western Ghats, which clearly shows its disjunct distribution and a new report from south India. Nayar and Sastry (1990) included this species in the Red Data Book of Indian Plants and placed it under rare and threatened category. A brief description with ecological notes is provided for better understanding of this endemic and little known taxon.

\section{Gymnema khandalense}

Sant., Kew Bull. 1948: 486. 1949 \& Rec. Bot. Surv. India 16:52. 1967; Kothari \& Moorthy, J. Bombay Nat. Hist. Soc. 80: 259. 1983; Nayar \& Sastry, Red Data Book Indian Pl. 3: 37. 1990; Sasi. \& Sivar., Fl. Plants of Thrissur Forests 289. 1996. Bidaria khandalense (Sant.) Jagtap \& Singh in Biovigyanam 16 (1): 62. 1990 \& Fasc. Fl. India 24. 1999.

Specimens examined: Three mature individuals were observed, 20.xi.2003 and 29.xi.2003, Nilakkal to Pampavalley (Attathode), forests near Sabarimala, Pathanamthitta District, Kerala State, \pm 300m, coll. P.S. Udayan et al., 02101 and 02113.

Distribution: Endemic to the Western Ghats of Maharashtra (Khandala Ghat of Pune District; Masadi forests in Roha of Raigad District; Kolhapur District) and of Kerala (Vazhachal of Thrissur District).

Description: Large climbing shrubs; mature stem corky, ca. $6 \mathrm{~cm}$ in diameter; young stem lenticellate and tender stem pubescent. The latex is milky white when cut. Leaves opposite, broadly elliptic-ovate, acute-acuminate at apex, truncate at base, subcoriaceous, densely tomentose below and sparsely above, $8-12.5 \times 5-8 \mathrm{~cm}$; lateral nerves five or six pairs; petiole terete, densely tomentose, $3-3.5 \mathrm{~cm}$ long. Flowers slightly fragrant, puberulous, in axillary umbellate cymes, $0.8-1 \mathrm{~cm}$; peduncles ca. $1 \mathrm{~cm}$ long; pedicel about $0.7 \mathrm{~cm}$ long. Calyx lobes oblong, acute, yellowish-green, 1-1.2mm long, outer surface and margins pubescent. Corolla yellow, campanulate, to 3-3.5 x 1-1.2mm; lobes fleshy, triangular, prominently pubescent on inner surface and ciliolate along margins. Corona of five hairy, fleshy processes arising from and adnate to the corolla tube, alternating with the corolla lobes. Ridges of the corona slightly protruding the corolla tube. Translators five, ca. $0.3 \mathrm{~mm}$ the pollinia yellow and the corpusculum red. Gynostegium about $2 \mathrm{~mm}$ long. Fruits not collected (Image $1^{\mathrm{w}}$ ).

\section{Flowering: October-December}

Biotic association: This endemic climber is rare and found to grow near moist and shady localities of semi evergreen forests. It is seen growing on Macaranga peltata (Roxb.) Muell.-Arg. along with straggling Acacia pennata (L.) Willd. Other associated climbers are Sarcostigma klenii Wight \& Arn., Piper argyrophyllum Miq., Anamirta cocculus (L.) Wight \& Arn., Miquelia dendata Bedd., Mikania micrantha Kunth, Thunbergia mysorensis (Wight.) Anders., Chonemorpha grandiflora (Roth) M.R. \& S.M. Almeida, Strychnos colubrina L., Tetrastigma sulcatum (Lawson) Gamble etc and shrubs like Dendrocnide sinuata (Blume) Chew, Dichapetalaum gelonioides (Roxb.) Engl., Clerodendrum viscosum Vent., Leea indica (Burm.f.) Merr., Nothopegia beddomei Gamble and trees such as Xanthoxylum flavascens Roxb., Canarium strictum Roxb., Grewia tiliifolia Vahl, Antiaris toxicaria Lesch., Myristica malabarica Lam., Knema attenuata (Wall. ex Hook.f \& Thoms.) Warb., Alstonia scholaris (L.) R. Br., Prunus ceylanica (Wight)

w See Image 1 in the web supplement at www.zoosprint.org 